\title{
The Effectiveness of Motivated Spalk on Children's Anxiation Assessed from Science Development Study
}

\author{
Reni Mareta ${ }^{1}$, Suryo Ediyono ${ }^{2}$, Indri Chrisvianti ${ }^{3}$ \\ \{renimareta@ummgl.ac.id ${ }^{1}$ \} \\ Faculty of Health Sciences, University of Muhammadiyah Magelang, Indonesia ${ }^{1,3}$ \\ Faculty of Cultural Science, Universitas of Sebelas Maret ${ }^{2}$
}

\begin{abstract}
Purpose: to determine the effectiveness of using patterned spalk on the level of anxiety in children who have an IV in the children's ward at RSUD Muntilan. The method used in this study was a quasi-experimental study using 2 groups of pres test and post test with a control group and an intervention group. Respondents in this study were 52 child respondents in the children's ward at RSUD Muntilan, by using purposive sampling technique. The measuring instrument used to measure the level of anxiety of children aged 1 to 6 years uses the SCAS (Spance Children's Anxiety Scale) and the observation sheet. Result: there is a significant effect on the level of anxiety of the child who is given. The act of using spalk is patterned in the intervention group with $\mathrm{p}$ value $=0.000(\mathrm{p}<0.05)$. There was a positive effect on the children who were attached with patterned spalks, the children looked happy and the anxiety decreased compared to the children who only wore plain spalk wrapped in gauze. So that the use of patterned spalk on children who have the IV line is proven to be effective in reducing anxiety levels.
\end{abstract}

Keywords: Anxiety, patterned spalk, scientific development

\section{Introduction}

Spalk is a tool used to restrict motion between the bones and joints. Spalk can also be a tool used to limit the movement of venous access or the area being infused to keep it in the correct position and also to prevent unnecessary movement, infiltration or inflammation. Spalking is done in patients who have fractures, patients who have an IV, especially in infants and children, in patients with joint dislocations and joint pain [7].

Spalk in its development has changed in terms of motifs and colors. The development of this spalk occurs because science is growing and the more results of this research can be used and utilized. The development of this knowledge begins by using patterns and motifs on the splint or spalk, where these patterns and splints will bring a new atmosphere for the child being cared for, besides choosing a color that suits the goals to be achieved. By choosing a suitable pattern and color will reduce anxiety in children who are being treated in hospital and receiving intravenous therapy.

Anxiety is a condition where the body gets a signal that warns of a threatening danger and usually someone takes action to protect themselves. The response to anxiety in pre-school age children who are being treated in the hospital will affect various things such as children having excessive anxiety and feeling afraid of the environment around them. One of the causes of 
anxiety is when the child will be put on an IV to get intravenous therapy. The child will experience anxiety when the IV is placed and must be fixed with a spalk or splint. Based on these observations, research will be carried out on how the effectiveness of using patterned spalk to reduce the anxiety of children who are placed with an IV in terms of scientific developments.

\section{Method}

This study was conducted from November to July with a total population of 97 toddlers who were treated in the children's ward and received infusion therapy. Sampling using purposive sampling technique and divided into two groups, namely the control group and the intervention group, so that each group is 26 children. The instrument used to measure the level of anxiety is the Spance Children's Anxiety Scala (SCAS), which is a tool for measuring the level of anxiety in pre-school children with a total score of 112 , and is divided into three levels, namely mild anxiety with a score of 1-38, moderate anxiety with a score. 39-76, and severe anxiety with a score of 77-112. This instrument consists of 29 questions.

The intervention was given to children who had the infusion on the first day by providing a patterned spalk with a color that matched the child's choice. The measurement of the level of anxiety was carried out twice for both the intervention group and the control group. This assessment is carried out before and after the action is taken

Univariate analysis was carried out to determine the characteristics of the response including day of care, age, gender, experience in care. While bivariate analysis is used to test the hypothesis by determining the relationship between two variables, namely the independent variable and the dependent variable using statistical tests. The statistical test used in this study is to use the dependent $t$ test and independent $t$ test. The test is used if the distribution is normal, if the distribution is not normal then use the Whitney mann test

\section{Results and Discussion}

In this study, there were two groups, namely the intervention group which was given spalk with a pattern of various colors and the control group which was only given plain spalk wrapped in white gauze.

\subsection{Characteristics of respondents in age and gender}

Based on Table 1, anxiety that occurs while the child is hospitalized due to the emergence of stress in the child caused by separation from the people closest to him and pain [10]. One of the factors in children's anxiety is age. Toddler age is a period of autonomy so that if there are disturbances or restrictions on movement that makes it uncomfortable. Like being put in an infusion, besides causing anxiety it will also cause the child to react negatively, especially temper tantrums. Anxiety is also influenced by gender which girls have higher anxiety than boys. 
Table 1. Characteristics of respondents in age and gender

\begin{tabular}{|c|c|c|c|c|c|c|}
\hline \multirow[t]{2}{*}{ No } & \multirow[t]{2}{*}{ Variable } & \multirow{2}{*}{$\begin{array}{l}\text { Intervention } \\
\text { Frequency }\end{array}$} & \multirow{2}{*}{$\begin{array}{l}\text { group } \\
\text { Percentage }\end{array}$} & \multirow{2}{*}{$\begin{array}{r}\text { Control } \\
\text { Frekuensi }\end{array}$} & \multirow{2}{*}{$\begin{array}{l}\text { group } \\
\text { Prosentase }\end{array}$} & \multirow{2}{*}{$\begin{array}{c}\text { Homogen } \\
\text { nitas }\end{array}$} \\
\hline & & & & & & \\
\hline \multirow[t]{7}{*}{1} & Age (year) & & & & & 0,074 \\
\hline & 1 & 3 & $36 \quad 1,5 \%$ & 3 & $11,5 \%$ & \\
\hline & 2 & 3 & $11,5 \%$ & 4 & $15,4 \%$ & \\
\hline & 3 & 2 & $7,7 \%$ & 1 & $3,8 \%$ & \\
\hline & 4 & 7 & $26,9 \%$ & 6 & $23,1 \%$ & \\
\hline & 5 & 3 & $11,5 \%$ & 4 & $15,4 \%$ & \\
\hline & 6 & 8 & $30,8 \%$ & 8 & $30,8 \%$ & \\
\hline \multirow[t]{4}{*}{2} & Gender & & & & & 0,321 \\
\hline & Male & 11 & $42,3 \%$ & 15 & $57,7 \%$ & \\
\hline & Female & 15 & $57,7 \%$ & 11 & $42,3 \%$ & \\
\hline & Amount & 26 & $100 \%$ & 26 & $100 \%$ & \\
\hline
\end{tabular}

\subsection{Characteristics of Respondents based on length of stay and history of care}

Table 2. Characteristics of respondents based on length of stay and history of care

\begin{tabular}{|c|c|c|c|c|c|c|}
\hline \multirow[t]{2}{*}{ No } & \multirow[t]{2}{*}{ Variabel } & Intervention & Group & Control & Grup & \multirow{2}{*}{$\begin{array}{c}\text { Homogen } \\
\text { nitas }\end{array}$} \\
\hline & & Frekuensi & Prosentase & Frekuensi & Prosentase & \\
\hline \multirow[t]{8}{*}{1} & $\begin{array}{l}\text { Length of } \\
\text { Stay (day) }\end{array}$ & & & & & 0,061 \\
\hline & $\overrightarrow{4}$ & 15 & $57,7 \%$ & 10 & $38,5 \%$ & \\
\hline & 5 & 3 & $11,5 \%$ & 4 & $15,4 \%$ & \\
\hline & 6 & 4 & $15,4 \%$ & 5 & $19,2 \%$ & \\
\hline & 7 & 1 & $3,8 \%$ & 1 & $3,8 \%$ & \\
\hline & 8 & 1 & $3,8 \%$ & 3 & $11,5 \%$ & \\
\hline & 9 & 1 & $3,8 \%$ & 1 & $3,8 \%$ & \\
\hline & 10 & 1 & $3,8 \%$ & 2 & $7,7 \%$ & \\
\hline \multirow[t]{4}{*}{2} & Being Treated & & & & & 0,341 \\
\hline & Yes & 15 & $57,7 \%$ & 11 & $42,3 \%$ & \\
\hline & No & 11 & $42,3 \%$ & 15 & $57,7 \%$ & \\
\hline & & 26 & $100 \%$ & 26 & $100 \%$ & \\
\hline
\end{tabular}

Based on Table 2, the length of treatment period also affects the level of anxiety, according to Wong [10], which states that parents will feel anxious when a child is treated for the first time and anxiety becomes less if they often care for their child in the hospital. This parent's anxiety will automatically have an impact on the child and spread to the child, causing the child's level of anxiety to also increase. This is in line with Subandi's research [7] which states that the experience of children in previous hospitals is a support system as well as the ability of children to respond to hospotalization anxiety in children. According to Wong [10] also states that the vulnerability of children will increase to hospitalization stress, one of which is in children aged 6 months to 5 years. However, the response of pre-school children to the effects of hospitalization is much better than that of younger children. The existence of both verbal and physical aggression only leads to a certain destination or place, not the whole body. Preschool children are also able to explain the level of pain more clearly and are more courageous to verbally convey their dislike to nurses.

The psychosocial stage of development in preschool children has a more frightening experience when compared to other children. The experience of the child being treated in the hospital will show various reactions depending on the stage of development, the child's experience in hospitalization, support from family, support from sibling and the ability to adjust the place of the clutch it has. In addition, the longer the patient is treated in the hospital, it will cause a decrease in the level of anxiety because the child has adapted to a new environment, new procedures and habits, is familiar with people who interact every day, both from a team of doctors, nurses and other health teams. 


\subsection{The difference in the average level of anxiety before and after the use of patterned spalk}

Based on Table 3, at the age of 1-6 years is a period where children become very sensitive to new environments

Table 3. The difference in the average level of anxiety before and after the use of patterned spalk

\begin{tabular}{lcccc}
\hline Group & Mean & D & Sd & \multicolumn{2}{c}{ P Value } & \\
\cline { 2 - 3 } & Before & After & & \\
\hline Intervensi & 49,88 & 71,04 & 13,107 &, 000 \\
\hline Kontrol & 64,62 & 120,73 & 29,698 &, 000 \\
\hline
\end{tabular}

. At this time is the peak period of worry in children. Their limited understanding of body functions also increases their difficulty in understanding their bodies, one of which is when the nurse is about to put an IV. At this time the reaction to the appearance of pain is the same as that seen in toddlers, even though pre-school children can already determine the level of pain precisely. Pre-school age children already understand that if given an explanation of the interventions to be carried out, explanations and distractions, this will have an effect on reducing anxiety levels. The usual response to children with anxiety during hospitalization and intervention is that they will try to stay away or hide the tools to be used

Based on the Cognitive development theory put forward by Peaget, it is stated that children aged 2-7 years are in the preoperational phase where children's minds are dominated by what they see, hear and experience [10]. At this age children are also able to use the language and symbols that exist in their environment. This is usually done by imaginative play, asking questions and other interactions so that at this time the child can be involved in choosing the motifs and colors on the spalk according to their wishes

Research conducted by Subandi [7] shows that there are significant differences in the cooperative level of the intervention group and the control group with a $\mathrm{p}$ value of 0.000 . This shows that the cooperative attitude is greater in the intervention group than in the control group. The selection of colorful and patterned spalks is in accordance with the principle of atraumatic care, which according to Wong et al. [10] atraumatic care is an effort to reduce children's anxiety while in hospital by providing a comfortable environment by health workers, and using interventions that eliminate or reduce physical or psychological distress in children and families in the health care system. Childhood is a period when the child begins to exercise self-control so it is appropriate that at this age the child is given the opportunity to choose the appropriate spalk motif. It is hoped that this patterned spalk will be able to reduce pain and injury to children because this can be a way to avoid physical distress. This is in accordance with Wong et al [10] which states that one of the principles of atarumatic care is to reduce physical distress, which can be done by modifying the room as well as the condition of the house, installing looms or bed linen with animal and flower motifs and paint walls by using bright color paint.

\subsection{The Effect of the Use of Patterned Spalk on the Anxiety Level of the Infused Children}

Difference in the average level of anxiety before and after the use of patternes spalk showed on Table 4. 
Table 4. The difference in the average level of anxiety before and after the use of patterned spalk

\begin{tabular}{lccccc}
\hline & $\mathrm{N}$ & $\mathrm{D}$ & $\mathrm{SD}$ & $\mathrm{F}$ & $\mathrm{Sig}$ \\
\hline Intervention & 26 & 71,04 & 13,107 & 18,363 & 0,000 \\
Control & 26 & 120,73 & 29,698 & & \\
\hline
\end{tabular}

The results showed that there was an effect on the level of anxiety that was installed with patterned spalk. This is in line with Susila's research which shows that children are more cooperative after being given intervention to use patterned medical devices. Modification of the use of patterned medical devices, one of which is a patterned spalk, is essentially a scientific development based on the philosophy of child nursing care. The philosophy of nursing care for infants and children is the diagnosis and response to human response to health problems that arise both actually and potentially. In this philosophy includes four images including: attention to a series of experiences and human responses to health and disease without being limited to a problem-focused orientation, directly integrated with objective data with knowledge gained from understanding the subjective experience of patients or groups, the application of knowledge on the process of diagnosis and treatment as well as establishing caring relationships that facilitate health and healing [11].

This spalk modification using motifs and colors is basically an application of scientific knowledge that is always developing. In philosophy, a scientific discipline can be stated as knowledge if it meets the criteria of the ontology which includes what / the essence of science / truth / science. Meanwhile, epistemonology includes methods and paradigms as well as axiology that includes imperative goals or values or attitudes. Philosophy itself is divided into 2 fields of science, namely natural science and moral science.

Nursing which is part of health and is part of natural sciences because one of it is the study of life sciences. Science is always developing and one of them is the development of this splint or spalk. The development can be seen from the appearance of spalk which used to be limited to using a board wrapped in white cloth and then developed into a form of board covered with cotton and wrapped in gauze. Along with the development of science and the results of research, finally, the domination with various motives is evident and this is evident from some of the research that has been done.

Apart from developing with various motifs, spalk also develops by using a variety of colors. It has also been proven from several research results that certain colors also have a psychological effect on a person. According to Atkinson in Harini [2], there are two ways to deal with a person's anxiety, namely first by focusing on the problem, individuals assess situations that can cause anxiety and do something to change or avoid it. Second, emphasize emotions, where individuals try to reduce feelings of anxiety through various ways and indirectly deal with problems that cause anxiety. So, someone who experiences anxiety will be able to overcome his anxiety in his own way. Color plays an important role in a person's life. One of the psychological functions of color is that it can have a certain effect on our temperament and our soul. Color can affect human soul and emotions and can describe mood. Color has a special influence on our bodies even though we are sometimes not aware of it. There are several color actions on the body such as red improves blood circulation, blue inhibits and yellow helps reduce pain and inflammation, in addition to that, green shark has a nourishing and calming effect, as well as blue also has a calming and relaxing effect. 


\section{Conclusion}

The use of patterned spalk with a choice of colors has a positive impact on reducing children's anxiety while being treated in the hospital. It is proven that there is a positive relationship because patterned spalk has a relatively low level of anxiety in children compared to children who only use plain spalk. Children prefer spalk with animated characters and colorful motifs.

\section{References}

[1] Fazrin I, Saputro H. (2017). Penurunan Tingkat Kecemasan Ana Akibat Hospitalisasi Dengan Penerapan Terapi Bermain. Jurnal Konseling Indonesia. Vol. 3 No.1, pp 9-12. http://ejornal.unikama.ac.id/index.php/jki

[2] Harini N, (2013) Terapi Warna untuk Mengurangi Kecemasan, Vol. 01, No. 02, Agustus 2013, Hal 291-303, Fakultas Psikologi Universitas Muhammadiyah Malang, http://ejournal.umm.ac.id/index.php/jipt/article/view/1584/1688

[3] Ilmiasih R,Nurhaeni N,Waluyanti FT.(2012). Pengaruh Seragam Perawat: Rompi Berseragam Terhadap Kecemasan Anak Pra Sekolah Akibat Hospitalisasi. Tesis. Depok

[4] Mutiarawati F, Agustina T, (2008) Tinjauan Filsafat Kesehatan Reproduksi. Jurnal Kesehatan Masyarakat Nasional. Vol. 3, No.3, Desember 2008, Hal 126-132.

[5] Muscari, M.E. (2005). Panduan Belajar: Keperawatan Pediatrik. Jakarta: EGC dalam Anggika. A. Wahyuni. Tingkat Kecemasan Pada Anak Pra Sekolah Yang Mengalami Hospitalisasi Berhubungan Dengan Perubahan Pola Tidur Di RSUD Karanganyar. Gaster Vol. XIV No. 2.

[6] Paramita Iga, Wijayanti K, Mareta R. (2017). Pengaruh Bercerita Menggunakan Audiovisual Terhadap Tingkat Kecemasan Anak Usia Prasekolah Di Rumah Sakit Harapan. Skripsi: Fakultas ilmu Kesehatan Universitas Muhammadiyah Magelang

[7] Subandi A, Nurhaeni N, Agustini N. (2012). Pengaruh Pemasangan Spalk Bermotif Terhadap Tingkat Kooperatif Anak Usia Pra Sekolah Selama Prosedur Injeksi Inra Vena Di Rumah Sakit Wilayah Cilacap. Tesis. Depok

[8] Supartini Y.2012. Buku Ajar Konsep Dasar Keperawatan Anak. Jakarta: EGC

[9] Kirom S, (2011), Filsafat Ilmu dan Arah Pengembangan Pancaasila: Relevansinya dalam Mengatasi Persoalan Kebangsaan, Jurnal Filsafat Vol. 21, Nomor 2, Agustus 2011, Hal 99-117

[10] Wong DL, Hockenberyy, Eaton M, Wilson D. (2009). Buku Ajar Keperawatan. Jakarta: EGC

[11] Yusuf, Syamsu. (2011). Psikologi Perkembangan Anak dan Remaja. Jakarta: PT. Remaja Rosdakarya 